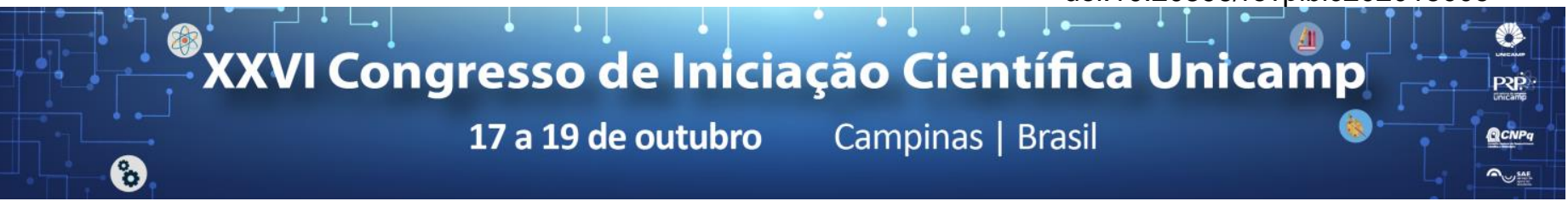

\title{
Estudo e Desenvolvimento de um robô paralelo didático para ensino de cinemática
}

\author{
Hugo T. M. Secreto*, Ludmila C. de A. e Silva.
}

\section{Resumo}

Este trabalho se situa na área de robótica paralela, aonde foi estudada a cinemática de um robô paralelo planar 3RRR para a confecção de uma plataforma didática, já que é um mecanismo de simples construção e ideal para ensino. Para chegar a essa conclusão, foi feita uma extensiva revisão bibliográfica de vários tipos de robôs paralelos e suas características. Além disso, foram estudados vários aspectos do robô objeto de estudo. O resultado é um robô modelado em Matlab segundo a cinemática estudada. Também foi feito um modelo em 3D para uso no software de simulação Adams e um para futura construção da plataforma didática.

\section{Palavras-chave:}

robô paralelo, cinemática, graus de liberdade

\section{Introdução}

Ao longo da história, foram surgindo robôs cada vez mais sofisticados e com cinemática e dinâmica mais complicadas de serem calculadas. Entre eles, estão os do tipo paralelo que se caracterizam por serem construídos em uma cadeia cinemática fechada. Estes têm várias vantagens em relação aos robôs seriais.

Tendo em vista a importância do estudo desses robôs, o objetivo deste trabalho é a construção de uma plataforma didática para ensino da cinemática de um mecanismo paralelo no ambiente virtual e discussão de como pode ser construído um protótipo real.

\section{Resultados e Discussão}

Para a elaboração do robô escolhido no ambiente virtual foi feito um programa na linguagem do software Matlab, aonde foi modelada toda a cinemática inversa do robô como descrito em [1]. É possível ver um fluxograma do funcionamento do programa na figura 1.

Entrada: é definida a equação variante no tempo da posição desejada da plataforma $(x, y, \varphi)$

$$
\begin{array}{|c|}
\text { Saída: ângulo de cada uma das juntas para a posição desejada } \\
\text { Resposta visual dos ângulos calculados para o robô } \\
\text { Equação de entrada é derivada da cinemática inversa para a velocidade } \\
\text { Saída: velocidade angular de cada uma das juntas do robô }
\end{array}
$$

Figura 1. Fluxograma do programa.

A resposta visual do programa dadas equações variantes no tempo como entradas pode ser vista na figura 2 .

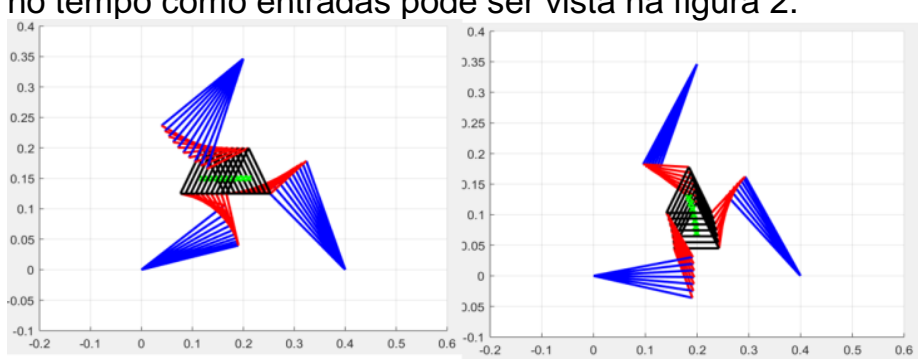

Figura 2. Modelo no ambiente Matlab.

Além disso, foi feito um modelo no software de desenho 3d para uso no ambiente de simulação MSC Adams (figura 3). Foram utilizados os ângulos obtidos como resposta no Matlab para o controle das juntas motoras no Adams e verificou-se que os movimentos são equivalentes nas duas simulações.

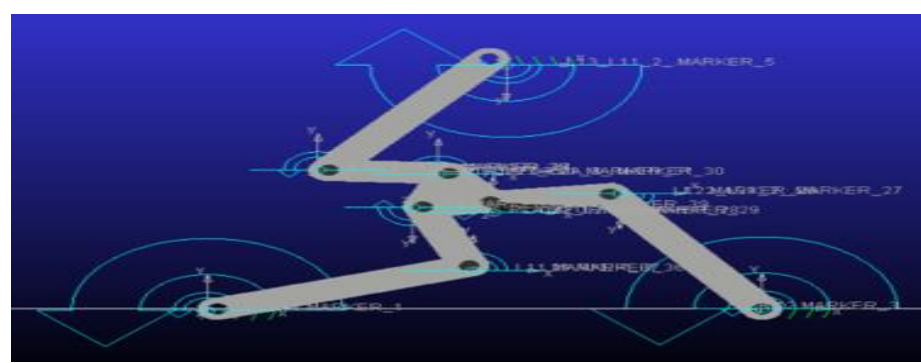

Figura 3. Mecanismo no ambiente Adams.

O protótipo real para fins didáticos foi desenhado em $3 d$ (figura 4) e tem como objetivo didático, quando construído, a conferencia se o comportamento virtual modelado tem o mesmo comportamento do mecanismo real. Para isso, na plataforma do robô será colocada uma caneta e na base, uma folha com as devidas marcações de coordenadas.

Dada uma curva desejada, será possível verificar se a cinemática real e a simulada estão de acordo. Todas as peças exceto a base podem ser impressas em uma impressora de prototipagem rápida. A base, por precisar de um acabamento liso, pode ser feita de acrílico.

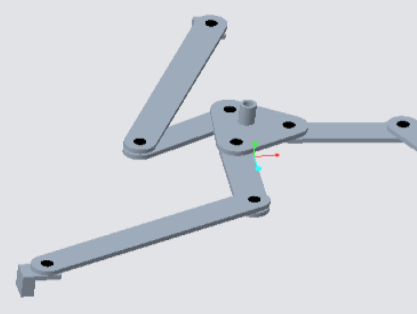

Figura 4. Desenho em 3d do protótipo real.

\section{Conclusões}

Este trabalho propôs um modelo de robô paralelo para ensino de cinemática. Conclui-se que a modelagem virtual do mecanismo está correta, pois existe o mesmo comportamento em dois programas de simulação diferentes e o protótipo real será enriquecedor para o ensino da cinemática de robôs paralelos.

\section{Agradecimentos}

Agradeço à equipe do Laboratório de Sistemas Integrados pelo apoio ao longo do projeto.

${ }^{1}$ WILLIAMS, R. L.; SHELLEY, Brett H. Inverse kinematics for planar parallel manipulators. In: Proceedings of ASME Design Technical Conferences. 1997. p. 14-17. 